\title{
Research on the Relationship among the Total Factor Productivity of Three Industries in China
}

\author{
Lihui Wang \\ School of Statistics and Mathematics, Zhejiang Gongshang University, Hangzhou 310000,China. \\ wlh310033@163.com
}

Keywords: Total factor productivity, primary industry, secondary industry, tertiary industry.

\begin{abstract}
In order to study the relationship among the total factor productivity of three industries, the Vector Autoregression Model (VAR) was applyed in this paper on the basis of the existing literature research. The conclusion is that the secondary industry technology progress and the tertiary industry technology progress promote the primary industrial technology progress, the primary industry and the tertiary industry technological progress promote the technological progress of the secondary industry. The innovation of this paper is that it distinguished among three industries to study the relationship of the total factor productivity.
\end{abstract}

\section{Introduction}

Many scholars have studied the total factor productivity from different perspectives (Machek Ondrej and Hnilica Jiri, 2012; Ben Soltane Bassem, 2014; Yen-Chun Chou and Benjamin B.M. Shao, 2014; Jungsoo Park, 2012; Almas Heshmati and Subal C. Kumbhakar, 2011). Alberto Colino et al.(2014) examined the determinants of total factor productivity growth in 26 OECD countries between 1965 and 2010. Sangeeta Pratap and CarlosUrrutia(2012) explored the role of financial frictions in exacerbating the misallocation of resources and explaining this drop in total factor productivity (TFP). Frank Asche et al.(2013) analyzed total factor productivity change in the Norwegian salmon aquaculture sector from 1996 to 2008. Yu Sheng and Ligang Song(2013) Used the firm-level census data to re-estimate the total factor productivity of firms in China's iron and steel industry and examine its potential determinants over the period 1998-2007. Kok Fong See and Fei $\mathrm{Li}(2015)$ examined the total factor productivity change of the UK airport industry from 2001 to 2009 using a Hicks-Moorsteen index method and got the conclusion that the industry experienced an average annual growth in TFP of 0.32 per cent.

Based on the existing literature research, this paper studied the relationship between the total factor productivity of the three industries in China from 1952 to 2013.

\section{Model, Index and Data}

According to the Douglas production function, the relationship between the output and the input can be expressed as:

$Y=A K^{\alpha} L^{\beta} \mu$

Therefore, the calculation formula of total factor productivity can be obtained as follows:

$$
T F P_{t}=\frac{Y_{t}}{K^{\alpha} L^{\beta}}
$$

Y refers to the total industrial output value, represented by actual GDP, which is deflated by GDP deflator. $\kappa$ and ${ }_{L}$ refer to the input of capital and labor. $\alpha$ and $\beta$ refer to the output elasticity of capital and labor respectively. $\mu$ refers to random perturbation term. Taking logarithm of TFP, this paper get LNPTFP as the index of the total factor productivity of the primary industry, and get LNSTFP as the index of the total factor of the secondary industry, LNTTFP as the index of the total factor productivity of the tertiary industry. Data in this paper are derived from the CSMAR database, the website of the Nationgal Bureau of Statistics of the People's Republic of China, the New China 60 Years Statistical Data Compilation and the "Quantitative Calculation Method on the Role Of 
Scientific and Technological Progress in Economic Growth” issued by the State Planning Commission of China in 1992.

\section{Empirical Analysis}

Stationary Test. In this paper, the ADF method is used to test stationarity of the total factor productivity of each industry. The test results are shown in table 1.

Table1 Variables Stationarity Test

\begin{tabular}{ccccccc}
\hline \multirow{2}{*}{$\begin{array}{c}\text { Test } \\
\text { sequence }\end{array}$} & $\begin{array}{c}\text { Test } \\
\text { form }\end{array}$ & $\begin{array}{c}\text { ADF test } \\
\text { statistic }\end{array}$ & \multicolumn{3}{c}{ The critical value of each significant } & Test result \\
\cline { 4 - 6 } & $(\mathrm{C}, \mathrm{T}, \mathrm{K})$ & & \multicolumn{3}{c}{ level } & \\
\cline { 4 - 6 } & & & $1 \%$ & $5 \%$ & $10 \%$ & \\
\hline LNPTFP & $(\mathrm{C}, \mathrm{T}, 0)$ & -2.159173 & -4.115684 & -3.485218 & -3.170793 & Unstatationary \\
\hline DLNPTFP & $(\mathrm{C}, \mathrm{N}, 0)$ & $-6.071282^{* * *}$ & -3.544063 & -2.910860 & -2.593090 & Stationary \\
\hline LNSTFP & $(\mathrm{C}, \mathrm{T}, 1)$ & -2.550908 & -4.118444 & -3.486509 & -3.171541 & Unstatationary \\
\hline DLNSTFP & $(\mathrm{C}, \mathrm{N}, 1)$ & $-9.040902^{* * *}$ & -3.546099 & -2.911730 & -2.593551 & Stationary \\
\hline LNTTFP & $(\mathrm{C}, \mathrm{T}, 0)$ & -1.269348 & -4.115684 & -3.485218 & -3.170793 & Unstatationary \\
\hline DLNTTFP & $(\mathrm{C}, \mathrm{T}, 0)$ & $-6.711633^{* * *}$ & -4.118444 & -3.486509 & -3.171541 & Stationary \\
\hline
\end{tabular}

Lag Test. According to the test results of Table 1, all the variables are 1 stage single integration, therefore can be tested by the cointegration test method. Through test, the variables are not cointegrated relationship. Therefore, the VAR model is constructed to analyze the relationship among the difference of these variables. The optimal lag period of the VAR model is determined in table 2 .

Table2 Variables Lag Length Test

\begin{tabular}{c|c|c|c|c|c|c}
\hline Lag & LogL & LR & FPE & AIC & SC & HQ \\
\hline 0 & 186.0048 & NA & $3.65 \mathrm{e}-07$ & -6.310512 & $-6.203937^{*}$ & -6.268999 \\
\hline 1 & 202.6125 & 30.92466 & $2.81 \mathrm{e}-07$ & -6.572846 & -6.146547 & -6.406794 \\
\hline 2 & 215.2656 & $22.25193^{*}$ & $2.48 \mathrm{e}-07^{*}$ & $-6.698813^{*}$ & -5.952791 & $-6.4082223^{*}$ \\
\hline 3 & 222.3824 & 11.77962 & $2.67 \mathrm{e}-07$ & -6.633877 & -5.568131 & -6.218748 \\
\hline
\end{tabular}

Table3 Test Results of VAR Model

\begin{tabular}{c|c|c|c}
\hline & DLNPTFP & DLNSTFP & DLNTTFP \\
\hline DLNPTFP(-1) & 0.262893 & 0.586038 & 0.218542 \\
& $(0.13994)$ & $(0.19808)$ & $(0.13459)$ \\
& {$[1.87859]$} & {$[2.95853]$} & {$[1.62372]$} \\
\hline DLNPTFP(-2) & -0.183736 & -0.101307 & 0.067111 \\
& $(0.13803)$ & $(0.19538)$ & $(0.13276)$ \\
& {$[-1.33110]$} & {$[-0.51850]$} & {$[0.50551]$} \\
\hline DLNSTFP(-1) & 0.184455 & -0.367784 & -0.129232 \\
& $(0.09765)$ & $(0.13822)$ & $(0.09392)$ \\
& {$[1.88894]$} & {$[-2.66084]$} & {$[-1.37600]$} \\
\hline DLNSTFP(-2) & -0.041195 & -0.419444 & -0.034880 \\
& $(0.09675)$ & $(0.13694)$ & $(0.09305)$ \\
& {$[-0.42581]$} & {$[-3.06292]$} & {$[-0.37486]$} \\
\hline DLNTTFP(-1) & 0.208330 & 0.412329 & 0.435929 \\
& $(0.15646)$ & $(0.22147)$ & $(0.15048)$ \\
& {$[1.33152]$} & {$[1.86182]$} & {$[2.89691]$} \\
\hline DLNTTFP(-2) & 0.211960 & -0.294157 & -0.088190 \\
& $(0.15769)$ & $(0.22321)$ & $(0.15167)$ \\
& {$[1.34411]$} & {$[-1.31783]$} & {$[-0.58146]$} \\
\hline C & 0.028213 & 0.033895 & -0.001478 \\
& $(0.01167)$ & $(0.01652)$ & $(0.01123)$ \\
& {$[2.41702]$} & {$[2.05148]$} & {$[-0.13146]$} \\
\hline
\end{tabular}




\begin{tabular}{c|ccc}
\hline F Statistics & 3.101418 & 5.283126 & 2.583148 \\
\hline AIC & & -6.748249 & \\
SIC & & -6.008787 & \\
\hline
\end{tabular}

VAR Model. According to table 2, there are four criteria of which the optimal lag period is 2 stage in the five criteria of LR, FPE, AIC, SC and HQ. Therefore, the 2 stage lag is chosen to construct the VAR model. The test results are shown in table 3.The number in the parentheses is the standard error and the T statistics in the brackets.

Granger Causality Tests. The granger causality tests of DLNPTFP, DLNSTFP and DLNTTFP are shown in table 4 , table 5 and table 6.

Table4 Granger Causality Tests of DLNPTFP and DLNSTFP

\begin{tabular}{c|l|c|c|c}
\hline Lag & Null Hypothesis & F Statistics & Prob. & Test Result \\
\hline 1 & DLNSTFP does not Granger Cause DLNPTFP & 7.63154 & 0.0077 & Reject \\
\cline { 2 - 5 } & DLNPTFP does not Granger Cause DLNSTFP & 3.91381 & 0.0527 & Reject \\
\hline 2 & DLNSTFP does not Granger Cause DLNPTFP & 4.75934 & 0.0125 & Reject \\
\cline { 2 - 5 } & DLNPTFP does not Granger Cause DLNSTFP & 4.67736 & 0.0134 & Reject \\
\hline 3 & DLNSTFP does not Granger Cause DLNPTFP & 3.13789 & 0.0332 & Reject \\
\cline { 2 - 5 } & DLNPTFP does not Granger Cause DLNSTFP & 4.08014 & 0.0113 & Reject \\
\hline
\end{tabular}

Table5 Granger Causality Tests of DLNPTFP and DLNTTFP

\begin{tabular}{c|c|c|c|c}
\hline Lag & Null Hypothesis & F Statistics & Prob. & Test Result \\
\hline \multirow{2}{*}{1} & DLNTTFP does not Granger Cause DLNPTFP & 7.04475 & 0.0103 & Reject \\
\cline { 2 - 5 } & DLNPTFP does not Granger Cause DLNTTFP & 5.07970 & 0.0281 & Reject \\
\hline \multirow{2}{*}{2} & DLNTTFP does not Granger Cause DLNPTFP & 5.34344 & 0.0076 & Reject \\
\cline { 2 - 5 } & DLNPTFP does not Granger Cause DLNTTFP & 2.73052 & 0.0742 & Reject \\
\hline \multirow{2}{*}{3} & DLNTTFP does not Granger Cause DLNPTFP & 3.18296 & 0.0315 & Reject \\
\cline { 2 - 5 } & DLNPTFP does not Granger Cause DLNTTFP & 2.33244 & 0.0850 & Reject \\
\hline
\end{tabular}

Table6 Granger Causality Tests of DLNSTFP and DLNTTFP

\begin{tabular}{c|c|c|c|c}
\hline Lag & Null Hypothesis & F Statistics & Prob. & Test Result \\
\hline \multirow{2}{*}{1} & DLNTTFP does not Granger Cause DLNSTFP & 1.94684 & 0.1683 & Accept \\
\cline { 2 - 5 } & DLNSTFP does not Granger Cause DLNTTFP & 3.14823 & 0.0813 & Reject \\
\hline 2 & DLNTTFP does not Granger Cause DLNSTFP & 2.13560 & 0.1280 & Accept \\
\cline { 2 - 5 } & DLNSTFP does not Granger Cause DLNTTFP & 1.69252 & 0.1937 & Accept \\
\hline 3 & DLNTTFP does not Granger Cause DLNSTFP & 1.55192 & 0.2124 & Accept \\
\cline { 2 - 5 } & DLNSTFP does not Granger Cause DLNTTFP & 1.96056 & 0.1316 & Accept \\
\hline
\end{tabular}

\section{Summary}

From the relationship between industrial production efficiency, the secondary industry technology progress and the tertiary industry technology progress promote the primary industrial technology progress. The primary industry and the tertiary industry technological progress promote the technological progress of the secondary industry. The primary industry technology progress promotes the technological progress of the tertiary industry. The secondary industry technological 
progress and the technological progress of the tertiary industry have been changed in a negative direction. The primary industrial production efficiency has a significant effect on the secondary industry and the tertiary industry production efficiency. The effect of the secondary industry production efficiency on the tertiary industry production efficiency is not more significant than the effect of the production efficiency of the primary industry, and the VAR model results show that the efficiency of the secondary industry is likely to have a reverse effect on the production efficiency of the tertiary industry, which possibly because that the resource allocation in the secondary industry production efficiency may has an extrusion effect on the production efficiency of the tertiary industry.

Therefore, the improvement of the production efficiency of the primary industry is the basis of the improvement of the secondary industry production efficiency and the tertiary industry production efficiency. so we should play the role of the first industry production efficiency to improve the production efficiency of the secondary and the tertiary industry. The secondary industrial production efficiency in the short term improve the production efficiency of the primary industriy because the primary industrial mechanization and modernization can not do without the support of the secondary industry. Therefore, we should strive to play the role of the secondary industry development improving the efficiency of the primary industrial production efficiency to improve the degree of agricultural modernization, so as to improve the efficiency of agricultural production. Because it is possible that the improvement of the secondary industry production efficiency has an extrusion effect on the production efficiency of the tertiary industry, so it should be more focused on the support of the tertiary industrial technology progress, so as to improve the production efficiency of all industries.

\section{References}

[1] Alberto Colino, Diana Benito-Osorio, Carlos Rueda-Armengot, Entrepreneurship culture, total factor productivity growth and technical progress: Patterns of convergence towards the technological frontier, Technological Forecasting and Social Change, 88 (2014) 349-359.

[2] Sangeeta Pratap ,CarlosUrrutia, Financial frictions and total factor productivity: Accounting for the real effects of financial crises, Review of Economic Dynamics, Volume 15, Issue 3 (2012) 336-358.

[3] Frank Asche, Atle G. Guttormsen, Rasmus Nielsen, Future challenges for the maturing Norwegian salmon aquaculture industry: An analysis of total factor productivity change from 1996 to 2008, Aquaculture. Volumes 396-399(2013) 43-50.

[4] Yu Sheng, Ligang Song, Re-estimation of firms' total factor productivity in China's iron and steel industry, China Economic Review. 24(2013) 177-188.

[5] Kok Fong See, Fei Li, Total factor productivity analysis of the UK airport industry: A Hicks-Moorsteen index method, Journal of Air Transport Management. 43 (2015) 1-10.

[6] Machek Ondrej, Hnilica Jiri, Total Factor Productivity Approach in Competitive and Regulated World , Procedia - Social and Behavioral Sciences. 57 (2012)223-230.

[7] Ben Soltane Bassem, Total factor productivity change of MENA microfinance institutions:A Malmquist productivity index approach, Economic Modelling. 39 (2014) 182-189.

[8] Yen-Chun Chou, Benjamin B.M. Shao, Total factor productivity growth in information technology services industries: A multi-theoretical perspective, Decision Support Systems. 62 (2014) 106-118.

[9] Jungsoo Park, Total factor productivity growth for 12 Asian economies: The past and the future, Japan and the World Economy.Volume 24, Issue 2 (2012) 114-127.

[10] Almas Heshmati, Subal C. Kumbhakar, Technical change and total factor productivity growth: The case of Chinese provinces, Technological Forecasting and Social Change, Volume 78, Issue 4 (2011) 575-590. 